7. Живих Т.Н. Групова форма роботи на уроках при навчанні іноземній мові студента з іноземній мові "Соціальна мережа працівників освіти" [Електронний ресурс] /Т.Н. Живих - 2013. Режим docmyny: www.nsportal.ru

\section{REFERENCES}

1. Gromova, O. J. Orhanizatsiia parnoi ta hrupovoi roboty na zaniattiakh z inozemnoi movy [Organization of pair and team work at a foreign language lesson]. [Electronic Resource]. Access Mode: www.rudocs. exdat.com/docs.

2. Lihachev, B. T. (1993). Pedahohika [Pedagogics]. Course of lectures. Moscov.

3. Passov, I.E. (1998). Urok z inozemnoi movy u serednii shkoli [Foreign language lessons at a secondary school]. Moscov: Education, 223p.

4. Pavlova, E.A. (2013/14). Orhanizatsiia hrupovoi roboty na urotsi $z$ inozemnoi movy [Organization of team form of work at a foreign language lesso]. "School of
Digital Century". [Electronic Resource]. Access Mode: www.testival.1september.ru/article/565289

5. Semushkina, L.G. \& Jaroshenko, N.G. (2001). Zmist ta tekhnolohii navchannia u serednikh spetsialnykh navchalnykh zakladakh [Contents and techniques of training in secondary specialized schools]. Guide for teachers of secondary vocational schools. Moscov: Skill, $272 \mathrm{p}$.

6. Varianko, T.V. (2013). Orhanizatsiini formy roboty pry navchanni inozemnoi movy studentiv tekhnichnykh spetsialnostei [Organizational forms of work used in the foreign language teaching of students of technical specialities]. [Electronic Resource]. International practical internet-conference "Modern methods of $f$ foreign language teaching”.

7. Zhivyh, T.N. (2013). Hrupova forma roboty na urokakh pry navchanni inozemnii movi studenta z inozemnii movi "Sotsialna merezha pratsivnykiv osvity" [Team form of work at a foreign language lesson "Social Network of Educators"]. [ Electronic Resource]. Access Mode: www.nsportal.ru

Стаття надійшла до редакції 16.01.2018

УДК 791.22

Мирослава Чайка, асистент кафедри тележурналістики та майстерності актора факультету кіно і телебачення

Київського національного університету культури і мистецттв

\title{
ДО ПИТАННЯ МОК'ЮМЕНТАРІ, ЯК ЖАНРУ КІНЕМАТОГРАФУ
}

Стаття присвячена одному з найактуальніших на сьогодні кіно- та тележанрів - мок'юментарі, безпосередньо його розвитку та зразкам у кінематографі і на телебаченні.

Досліджено емоційність та інтелектуальність кінематографу на прикладі кінематографічного $i$ телевізійного жсанру мок'юментарі (псевдо документальних фільмів).

В роботі постулюється та доводиться ігрова природа мок'юментарі та наявність у ньому базових ігрових засад, властивих як мистецтву загалом, так $і$ кінематографу зокрема, проаналізовано причини виникнення психології обману і властивості гри в мистеитві.

Ключові слова: мистецтво, гра, кінематограф, телебачення, фільм, мок'юментарі, псевдодокументалістика, містифікація.

Jim. 9.

Myroslava Chayka, Assistant of the Telejournalism and Mastery of Actor Department, Movie and Television Faculty Kyiv National University of Culture and Arts

\section{TO THE QUESTION OF MOCKUMENTARY, AS THE GENRE OF CINEMATOGRAPHY}

The article is devoted to one of the most relevant cinema and television genre - mockumentary, directly to its development and to samples in the cinema and on television.

Mockumentary (from English "to mock" and "documentary") - a genre that has an imitation of documentary, falsification and mystification. The development of the genre from the first finished samples (midtwentieth century). And it continues to follow the main tendencies of modern art, in which, thanks to the latest technologies, a virtual reality is created that replaces reality as such. Accordingly, the line between the actual fact and artistic fiction is completely leveled.

The emotionality and intellectuality of cinematography have been studied using the example of the cinematographic and television mockumentary genre (pseudo documentary films).

The game postulates and proves the game nature of mockumentary and the presence in it of basic game principles inherent in both art in general and cinematography in particular, the causes of the origin of the psychology of deception and the properties of the game in art are analyzed.

The main idea of the genre of mockumentary is to create a "different" life, based on the principles of delusion and play. The twentieth century taught people to be deceived and feel comfortable at the same time. 
Investigating the genre of mockumentary from the point of view of the game, it can be argued that this is a kind of "re-shaping" of reality (that is, the transformation of reality into images through which another reality opens up to us).

Directors understood this natural process, understood the psychology of deception, the properties of the game and invented a new technology with their methods, techniques, successful tricks. They have learned to create their own "almost real world" for the audience.

The game nature of art and the genre of mockumentary have a common property - the transformation of the external world. New views of the genre of mockumentary open up opportunities to find the emotionality and intellectuality of the cinema.

Keywords: art, a game, a cinema, television, a film, mockumentary, pseudo-documentary, mystification.

П остановка проблеми у загальному вигляді. В сучасній культурі останнім часом набирають обертів розповсюдження фільми жанру мок'юментарі (псевдодокументалістики). Бачачи, який резонанс у суспільстві дає той або інший фільм, у якому усе “по-правді”, кінематографісти почали створювати такі стрічки одна за однією. А відтак, привабливий жанр псевдо-документалістики сьогодення, переживає своєрідний бум. Зазвичай, основними ознаками цього жанрує: імітація документальності, використання прийомів містифікації $\mathrm{i}$ фальсифікації. Кінематограф є своєрідним мотивом, спонуканням до активного втручання у своє життя і зміни його на краще на шляху до ідеалу.

Заглядаючи в минуле сторінок кіно, можна прослідкувати поетапний розвиток та становлення кінематографу. Кінематограф відносно новий вид мистецтва. Його історія порівняно з тисячолітньою історією музики, живопису, театру дуже коротке. Але це не заважає кіно залишатися вже протягом декількох десятків років найбільш масовим видом мистецтва.

Аналіз основних досліджень і публікацій. Природа мистецтва та жанрове різноманіття, зокрема жанр мок'юментарі, привертали увагу дослідників, переважно філософів, таких як Арістотель, Платон, Кант, Шиллер, Флобеніус, Фінк та Гейзінг Й. Також цим напрямком цікавивсь Р. Барт, Х.-Г. Гадамер, Н. Брагінська. Докладно аналізував фільми та програми жанру мок'юментарі Роман Ширман.

Виклад основного матеріалу. Людина завжди прагне до краси, досконалості, гармонії, а мистецтво одна з найбільш яскравих форм їх втілення. Тому, сприймаючи мистецтво, людина задовольняє найважливішу з насущних духовних запитів свого бугтя. Відмінною рисою мистецтва $\epsilon$ не тільки його естетична, а й ігрова природа. Мистецтво, будучи грою, видозмінює часом об'єктивно дані форми, а сама людина, прийшовши у світ мистецтва, віддаляється і знову повертається до реальності, але вже $з$ дистанції вимислу. Отже, метою статті є розвиток та становлення жанру мок'юментарі як невід'ємної складової ігрової природи мистецтва.
Термін “мок'юментарі” з'явився тільки в середині 80-х років за допомогою складання двох слів "to mock" - "знущатися, насміхатися, підробляти" та "documentary" - “достовірний”. В літературі та наукових статтях тема мок'юментарі майже не опрацьована, окрім книги Романа Ширмана та статті С. Зельвенського та декількох публікацій в Інтернеті. Мок'юментарі стало набирати популярність в епоху бурхливого розвитку телебачення та інтернету. Адже кожен день на глядачів і читачів обрушується потік інформації, якій ми звикли вірити. Телебачення - це могутній організм, найбільший генератор фальсифікацій. Передумовою виникнення жанру мок'юментарі став перехід внугрішнього стану людей від “у газетах не брешугь” до “не вірю” по Станіславському.

Досліджуючи жанр мок'юментарі, з точки зору гри, можна надати окраси негативному забарвленню слова “брехня", надати йому цінності і значення. Ігрова природа мистецтва i жанр мок'юментарі мають спільну властивість перетворення зовнішнього світу. Відступивши від реалій життя, можна знайти новий вихід своїм ідеям, адже саме у грі "розігрується" щось таке, що перевищує безпосередні життєві потреби й надає цій дії певного смислу. Гра спирається на своєрідне “переобразування" дійсності (тобто, перетворення реальності на образи) [3]. Ці образи і становлять цінність, та за їх допомогою нам відкривається інша дійсність. Це, так зване, перетворення зовнішнього світу, гра на межі жарту та серйозності.

Слід зауважити, що фільми мок'юментарі, як правило, це фільми жахів, що охолоджують душу, проте, як виявилося, цей підклас застосований $\mathrm{i}$ до соціальних драм, і до комедій. Твори в жанрі мок'юментарі різноманітні, як по своєму змісту, так і по своїх художніх задачах. Частіше всього комедійні фільми жанру мок'юментарі використовуються в якості пародії і сатири. Жанр також використовується для аналізу актуальних подій і явищ на прикладі придуманого предмету фільму. Мок'юментарі свідомо надає глядачам можливість свого викриття. Основною ідеєю жанру мок'юментарі є створення “іншого” життя, 
основуючись на принципах омани та гри. Фальсифікація, омана стали настільки звичними, що будь-який сфабрикований факт знаходить безліч шанувальників. Сучасність навчила людей бути обманутими і почуватись при цьому комфортно. Жанр мок'юментарі спирається на “переобразування" дійсності, імітує та містифікує iii (себто гра обертається серйозним, а серйозне грою). Найхарактернішою рисою мок'юментарі в кіно є невідповідність форми і змісту.

На думку А. Менегетті, сучасне мистецтво "майже завжди шизофренічно змальовує хворобу, зізнаючись у власній обмеженості. Митець, вільний від кайданів раціональності, втілює латентну шизофренію, огортаючи у форму символи кодування за допомогою знаківнегативів, на які орієнтується егоїстична свідомість. Митець, як втілення вищої чутливості в суспільстві, відтворює його занепад та існування зла в реальності людини" [7, 21]. Доцільно зауважити, що мистецтво - це божественна гра, оскільки воно залишається мистецтвом лише до тих пір, поки ми пам'ятаємо, що в кінці кінців це всього лише вигадка, що акторів на сцені не вбивають, поки жах і огида не заважають нам вірити, що ми, глядачі, беремо участь у майстерній та захоплюючій грі; як тільки рівновага порушується, ми бачимо, що на сцені починає розгортатися безглузда мелодрама. Як зазначав Л. Виготський, мистецтво, будучи грою, долає матеріал дійсності; перетворює об'єктивно дані форми, часом істотно видозмінюючи їх. У цьому глибоко суб'єктивному процесі інтерпретації навколишнього світу та самовираження художника мистецтво дуже часто нехтує так званим “здоровим глуздом і логікою життя” [2, 233]. Мистецтво сьогодні нерідко є сховищем розщепленої свідомості. Обман - це така ж буденна і повсякденна річ, як чашка ранкової кави чи вечірній серіал по телевізору. Кожна людина використовує брехню у своєму повсякденному житті, не надаючи цьому великого значення.

На думку I. Канта, який стверджував, що людина приходить у світ мистецтва, віддаляючись і знову повертаючись до реальності, але вже 3 дистанції вимислу, ідеалу, “гри уяви” $[4,55]$. На сьогодні, коли наше сприйняття особливо сильно піддається впливу штампів і зразків масової культури, жанр мок'юментарі вибиває глядача 3 комфортного стану спокою і розслабленості. Зовнішня структура фільмів цього жанру нічим не відрізняється від документальних стрічок, але в основі - лежить вигаданий факт, спеціально замаскований під реальну подію. При перегляді стрічки, у глядача створюється враження знайомства з реальною достовірною історією, на що творці мок'юментарі і розраховують. Можливо, завдяки новим підходам, прийомам та ширшим поглядам режисерів мок'юментарі, сучасне кіномистецтво зможе інтелектуально та емоційно розвивати глядача. Цей жанр - чудовий спосіб повернути кінематографу втрачену абсолютну владу над емоціями публіки. Режисери виражали орієнтовану на масу ціннісну систему і ставили фільми, естетична програма яких була вкрай раціоналізованою і не передбачала свободи. Глядачеві нав'язувалася певна сума ідей: “При використанні аналітичного монтажу глядачеві залишається тільки прямувати за гідомрежисером, який робить вибір за нього і зводить до мінімуму його особисту активність" $[1,93]$.

Зважаючи на те, що класичні прийоми документального викладу відомостей вичерпують себе і перетворюють у звичні кліше, вони стають все менш дієвими для сучасного глядача, відомості, піднесені за допомогою стандартних прийомів перестають викликати углядача інтерес до оточуючої реальності. Незвичайний ракурс, шок, провокація - викликають в аудиторії шалену цікавість і змушують йти в кінотеатр. Таким чином, щоб завоювати увагу глядача в світі масового кіновиробництва, потрібна нова, несподівана форма подачі інформації, як у випадку з жанром мок'юментарі. Для глядача дійство фальсифікації псевдо реальності $€$ набагато привабливішим, аніж “реальні події” документального кіно, або дійсність телевізійних реаліті-шоу. Мок'юментарі демонструє процес виникнення нової реальності: плутає факти і підміняє поняття, дурить власних героїв і блефує, з'єднує непоєднуване і розрізає монолітне. Таким чином, ми бачимо, що, незважаючи на те, що жанр мок'юментарі спочатку виник як якась пародія на документальне кіно, поступово вбудовується та повністю підкоряє сучасне суспільство, а також є справжнім продуктом нашої епохи.

Слід зауважити, що в останні роки, псевдо документалістика стає все більш популярною, тому, що сучасне життя дуже схоже на картини в жанрі мок'юментарі. Коли телебачення показує нам одну картинку, фільм - другу, а самі ми бачимо третю - факти і домисли змішуються, довіряти стає складно, навіть, власним очам. Режисери користуються цим, обводячи навколо пальця не тільки наївних. Фільми цього жанру відмінні від буденного життя, тому більш схожі на гру режисера 3 глядачем. Ця гра називається перетворенням зовнішнього світу, це гра на межі 
жарту і серйозності. Конструюючи свою псевдо реальність, мок'юментарі використовує прийоми документального кіно, щоб створити в аудиторії враження реальності, що відбувається на екрані. Однак, такий “обман глядача" використовується як прийом, щоб спонукати аудиторію до саморефлексії та звернути іiі увагу на власну довірливість, а також на вироблену у неї сучасним телебаченням пристрасть до підлягання за чужим життям. Основним завданням жанру мок'юментарі є заплутати глядача, щоб він не здогадався, де правда, а де гра. Такі фільми часто цілком або частково $є$ імпровізаціями, оскільки імпровізація допомагає підтримувати видимість правдивості.

Мистецтво кінематографу з кожним виходом на екран дає можливість людині зануритись в ілюзорний світ, вийти з рамок “справжнього" життя в тимчасову сферу діяльності мистецтва кіно, де панують інші закони. У кіномистецтві, як і в мистецтві драматичному, сприйняття реальності, або активізованої в глядачі інформації, зумовлене емоцією актора [7, 37]. Образ людини на екрані постає перед глядачем як досить складне повідомлення, адже гра кіноактора має більш складну організацію, ніж театральний образ: ій властиве широке замінювання кодів в межах однієї ролі і більш глибокий семантичний зміст $[5,77]$.

Висновок. Узагальнюючи викладене вище, слід сказати, що народження кінематографа давало мистецтву ХX століття свободу у визначенні його зв'язків з іншими художніми формами. Створене в атмосфері наукового i технічного прогресу, кіно показувало ілюзію, як справжню реальність, але асоціювалося 3 їі антиподом - сновидінням. Здатність показувати "межу ілюзорного і реального" кінематограф знайшов завдяки монтажу, а виникнення звукового кіно надавало фільму можливість більшої синкретизації та карнавалізації.

Кіно - найбільш затребуване, і водночас, парадоксальне, суперечливе мистецтво XX - XXI століть. В момент виникнення воно стало, так званим, “культурним шоком" та стійко увійшло до життя людини. Кіно здатне задокументувати реальність, але цей документ може виявитися най достовірнішою фальсифікацією. Кіно показує ілюзію, як справжню реальність. Сьогоднішнє мистецтво дозволяє втілити в реальність світ фантазії, уяви, ірраціональності i, навіть, явний абсурд. Людству довелося звикнути до того, що не можна вірити своїм вухам, потім - ще й своїм очам з появою та розвитком жанру мок'юментарі. Нові погляди жанру мок'юментарі відкривають можливості віднайти емоційність та інтелектуальність кінематографу.

Отже, кінематограф, базуючись на основних “правилах гри” володіє дуже могутнім інструментом впливу на людей. Оскільки механізм гри побудований дуже простим та природнім шляхом, велика кількість людей, навіть, не звертає уваги на свій стан омани і не здогадується, що стає іграшкою в руках інших. Режисери, говорячи про мок'юментарі, як жанр кінематографу, стверджують, що він імітує дійсність, а не відбиває iii. Кіно здійснює в естетичному досвіді людства унікальні функції, і завдяки цьому визначається як спосіб фіксації часу. На думку А. Тарковського, кіно могло бути народжене лише культурою ХХ століття, оскільки саме тоді людина вступає у нові відносини з часом, починає відчувати особливий тиск часу $[8,82]$. Кінематограф не лише транслює, передає інформацію - він формує аудиторію, створює власного глядача. Складність структури людини на екрані інтелектуально і емоційно ускладнює людину в залі (i, навпаки, примітив створює примітивного глядача) $[6,59]$. Безсумнівність і значущість впливу кіномистецтва на сучасну людину актуалізує питання про глибоке вивчення механізмів і особливостей такого впливу. Сучасні дослідження виступають ізольованими спробами вивчення кінематографа, у той час як затребуваність кіно змушує говорити про необхідність системного дослідження цього об’ єкта.

\section{ЛITЕРАТУРА}

1. Базен А. Что такое кино? / А. Базен. - М., 1972. - C. 93.

2. Виготский Л. С. Избранные психологические исследования. / Л. Виготский. - М., 1956. - С. 435.

3. Зельвенский С. Моситеntary: история вопроса. C. Зельвенский. - // Сеанс. - Вып. 32, 2007. [Электронный ресурс].

4. Кант И. [Тартуская рукопись.] Публикачия Л.Н. Столовича. // Эстетика Иммануила Канта и современность. - М.: Знание, 1991. - С. 55-63.

5. Лотман Ю. М. Диалог с экраном. / Ю. М. Лотман, Ю. Г. Цивьян. - Таллинн, 1994. - 144 с.

6. Лотман Ю. М. Семиотика кино и проблемы киноэстетики. / Ю. М. Лотман. -Таллинн, 1973. - 92 с.

7. Менегетти А. Кино, театр, бессознательное. Том 1. / А. Менегетти. - М.: ННБФ Онтопсихология, 2001. -384 c.

8. Тарковский А. Запечатленное время. // Bопросы киноискусства. - Вып. 10. / А. Тарковский. - М., 1967. - C. 69-91.

9. Ширман Р. Н. Умное телевидение. / Роман Ширман. - Киев: Телерадиокурьер, 2011. - 359 с.

\section{REFERENCES}

1. Bazen, A. (1972). Chto takoe kino? [What is a movie?]. Moscow, 93p. [in Russian]. 
2. Vigotskiy, L. S. (1956). Izbrannye psikhologicheskie issledovaniya [Selected psychological research]. Moscow, 435 p. [in Russian].

3. Zelvenskiy, S. (2007). Mocumentary: istoriya voprosa [Mocumentary: the history of the issue]. Kyiv: Seans, 32. [Electronic resource]. [in Ukrainian].

4. Kant, I. (1991). Tartuskaya rukopis. Publikatsiya L. N. Stolovicha. Estetika Immanuila Kanta $i$ sovremennost [Immanuel Kant's aesthetics and modernity]. Moscow: Znanie, pp.55-63. [in Russian].

5. Lotman, Yu. M. (1994). Dialog s ekranom [Dialogue with the screen]. Tallinn, 144 p. [in Russian].
6. Lotman, Yu. M. (1973). Semiotika kino i problemy kinoestetiki [Semiotics of cinema and problems of cinema aesthetics]. Tallinn, 92p. [in Russian].

7. Menegetti, A. (2001). Kino, teatr, bessoznatelnoe. Tom 1. [Cinema, theater, unconscious]. Moscow: NNBF Ontopsikhologiya, 384p. [in Russian].

8. Tarkovskiy, A. (1967). Zapechatlennoe vremya [Imprinted time]. Moscow: Voprosy kinoiskusstva, 10, pp.69-91. [in Russian].

9. Shirman, R. N. (2011). Umnoe televidenie [Smart television]. Kyiv: Teleradiokurer, 359 p. [in Ukrainian].

Стаття надійшла до редакції 02.02.2018

УДК 373.5.017.4

Раїса Крат, директор Невірської загальноосвітньої школи I - II ступеня Любешівського району Волинської області

“Основа всієї держави полягає в правильному вихованні юнацтва”. Цицерон

\section{ВИХОВУСМО ГРОМАДЯНИНА}

Стаття присвячена проблемі громадянсько-патріотичного виховання дітей у школі та в позаурочний час. Метою статті є розкриття сучасних форм і методів громадянського виховання. Актуальність обумовлена прочесом становлення України як суверенної демократичної держави. Особлива увага акцентується на виховних заходах, які покликані формувати громадянина, патріота, інтелектуально розвинену, духовно і морально зрілу особистість, готову протистояти асоціальним впливам, вправлятися з особистими проблемами, творити себе і оточуючий світ.

Ключові слова: педагогічна майстерність, виховання, гуманізм, особистість, демократичні иінності, громадянин.

Лim. 8.

Rayisa Krat, Director of the Nevir Secondary School Lyubeshiv district of the Volyn region

"The basis of the whole state is the right education of youth".

Cicero

\section{EDUCATE A CITIZEN}

The article is devoted to the problem of the civic-patriotic upbringing of children at school. The purpose of the article is to reveal the contemporary forms and methods of civic education. Actuality is due to the process of becoming Ukraine as a sovereign democratic state. The process of the establishment of an independent democratic Ukraine with its aspirations to become a full member of the European community implies the comprehensive consolidation in the social and individual life on the basis of universal values and spiritual, moral and cultural principles of life of the Ukrainians. As historical experience shows, there is no nation without a state. And in order to save the state, including the nation, the problem of civic education should be actualized. In view of this, civic education is a powerful incentive in the struggle for the development of the state, the formation of high ethics of interethnic relations, the spiritual renewal of society. It is the task of the school to create the ability of students to have a stable civic position. The particular attention is paid to educational activities, which are designed to form a citizen, patriot, intellectually developed, spiritually and morally mature person, ready to resist asocial influences, deal with personal problems, and create oneself and the surrounding world. The conclusions drawn in the article can be used by teachers in the educational process and in extracurricular work.

Keywords: teaching skills, an education, humanity, personality, democratic values, a citizen.

П остановка проблеми. Початок XXI століття означено напруженим пошуком нового світорозуміння, нових перспектив розвитку компетентної особистості, спроможної створити свій життєвий проект, відповідально ставитись до життя, упевнено приймати історичний виклик тисячоліття.

Найважливішим завданням українського суспільства було і буде виховання покоління гуманістів і патріотів, для яких найвищим ідеалом 